\title{
Evaluation of feed value of a by-product of pickled radish for ruminants: analyses of nutrient composition, storage stability, and in vitro ruminal fermentation
}

Seoyoung Jeon, Keun-Nam Sohn and Seongwon Seo*

\begin{abstract}
Background: By-products of pickled radish (BPR) are considered food waste. Approximately $300 \mathrm{~g} / \mathrm{kg}$ of the total mass of raw materials becomes BPR. Production of pickled radish has grown continuously and is presently about 40,000 metric tons annually in Korea. The objective of the present study was thus to explore the possibility of using BPR as a ruminant feed ingredient.

Results: BPR contained a large amount of moisture (more than $800 \mathrm{~g} / \mathrm{kg}$ ) and ash, and comprised mostly sodium (103 g/kg DM) and chloride (142 g/kg DM). On a dry matter basis, the crude protein (CP) and ether extract (EE) levels in BPR were $75 \mathrm{~g} / \mathrm{kg}$ and $7 \mathrm{~g} / \mathrm{kg}$, respectively. The total digestible nutrient (TDN) level was $527 \mathrm{~g} / \mathrm{kg}$ and the major portion of digestible nutrients was carbohydrate; $88 \%$ organic matter (OM) was carbohydrate and $65 \%$ of total carbohydrate was soluble or degradable fiber. The coefficient of variation (CV) of nutrient contents among production batches ranged from 4.65 to $33.83 \%$. The smallest CV was observed in OM, and the largest, in EE. The variation in CP content was relatively small (10.11\%). The storage stability test revealed that storage of BPR at $20^{\circ} \mathrm{C}$ (room temperature) might not cause spoilage for $4 \mathrm{~d}$, and possibly longer. If BPR is refrigerated, spoilage can be deferred for $21 \mathrm{~d}$ and longer. The in vitro ruminal fermentation study showed that substitution of annual ryegrass straw with BPR improved ruminal fermentation, as evidenced by an increase in VFA concentration, DM degradability, and total gas production.
\end{abstract}

Conclusion: The major portion of nutrients in BPR is soluble or degradable fiber that can be easily fermented in the rumen without adverse effects, to provide energy to ruminant animals. Although its high sodium chloride content needs to be considered when formulating a ration, BPR can be successfully used as a feed ingredient in a ruminant diet, particularly if it is one component of a total mixed ration.

Keywords: By-product of pickled radish, In vitro fermentation, Nutrient composition, Ruminant feed, Storage stability

Abbreviations: A/P, Acetate/propionate; ADF, Acid detergent fiber; ADICP, Acid detergent insoluble crude protein; ADL, Acid detergent lignin; aNDF, neutral detergent fiber; ARS, Annual ryegrass straw; BPR, By-products of pickled radish; CM, Commercial concentrate mix; CNCPS, Cornell Net Carbohydrate and Protein System; CP, Crude protein; CV, Coefficient of variation; DM, Dry matter; EE, Ether extract; ESC, Ethanol soluble carbohydrate; HT, High temperature; IACUC, Institutional Animal Care and Use Committee; IVDMD, In vitro ruminal DM degradability; LT, Low temperature; NDICP, Neutral detergent insoluble crude protein; NEg, Net energy for growth; NEm, Net energy for maintenance; NFC, Non-fiber carbohydrates; OM, Organic matter; RT, Room temperature; TDN, Total digestible nutrient; TMR, Total mixed ration

\footnotetext{
* Correspondence: swseo@cnu.kr

Division of Animal \& Dairy Sciences, Chungnam National University, 99

Daehak-ro, Yuseong-gu, Daejeon, Republic of Korea
}

(c) 2016 The Author(s). Open Access This article is distributed under the terms of the Creative Commons Attribution 4.0 International License (http://creativecommons.org/licenses/by/4.0/), which permits unrestricted use, distribution, and reproduction in any medium, provided you give appropriate credit to the original author(s) and the source, provide a link to the Creative Commons license, and indicate if changes were made. The Creative Commons Public Domain Dedication waiver (http://creativecommons.org/publicdomain/zero/1.0/) applies to the data made available in this article, unless otherwise stated. 


\section{Background}

The use of by-products of food processing has been of great interest in the livestock industry. By-products are residues derived from the processing of raw materials to manufacture food products for sale. They usually contain some degree of digestible nutrients that can be used as livestock feed [1]. Most of these by-products however, are wasted. As the food industry is continuously being developed, the generation of food by-products has also increased. This results in economic losses and environmental challenges [2]. Thus, converting food by-products to valuable biomass has been an important issue in the scientific community for the last two decades [1].

In this regard, various by-products, mainly from agricultural and food processing, have been tested for their nutritive value as potential animal feeds [3]. However, there are several challenges associated with the use of food by-products as animal feeds. The nutrient composition of an animal feed needs to be consistent and predictable [3]. The nutrient composition of food byproducts however, can vary significantly according to the processing methods and condition of the raw materials, as well as their initial nutrient content [4]. Another major issue associated with food by-products is their moisture content. Most food by-products have a moisture content of more than $600 \mathrm{~g} / \mathrm{kg}$ [4]. High moisture levels can cause spoilage, which leads to a bio-security risk [3]. Therefore, to expand the use of food by-products as animal feed, the consistency of nutrient composition and storage stability of the byproducts should also be considered.

Many by-products are generated from the manufacture of pickled radish in Korea. By-products of pickled radish (BPR) comprise approximately $300 \mathrm{~g} / \mathrm{kg}$ of raw material and are generally wasted [5]. The market for pickled radish has grown rapidly and total production is estimated to be about 40,000 metric tons annually [5]. One manufacturer of pickled radish reportedly lost about 300 million Korean won in wasted BPR within a single year. Besides its significant generation, BPR contains digestible nutrients, such as crude protein $(60 \mathrm{~g} / \mathrm{kg})$ and crude fat $(30 \mathrm{~g} / \mathrm{kg})$ [6]. In addition, various digestive enzymes (e.g., amylase, amidase, and glycosidase) contained in the raw material (Raphanus sativus L.) might remain in BPR and act as bio-active factors that can promote feed utilization [7]. However, to our knowledge, no study has been conducted to evaluate the feed value of BPR.

Therefore, the objective of the present study was to investigate the feed value of $B P R$ as a ruminant feed ingredient. We tested the consistency of the nutrient composition of BPR and conducted fractionation and detailed chemical analysis. The storage stability of BPR at three different temperatures (i.e. $4{ }^{\circ} \mathrm{C}, 20{ }^{\circ} \mathrm{C}$, and
$37{ }^{\circ} \mathrm{C}$ ) was determined. In addition, the effects of BPR supplementation on rumen fermentation were analyzed.

\section{Methods \\ Sample preparation}

The by-product of pickled radish, mixes with peels and whole wastes, was obtained from a manufacturer (Ilga, Sejong, Korea) three times at approximately 1-month intervals on April 22, May 27, and July 6, 2015. The BPR sample from the last batch was used to test storage stability. For each batch, BPR was thoroughly mixed, sampled, frozen at $-80{ }^{\circ} \mathrm{C}$, and freeze-dried at $-50{ }^{\circ} \mathrm{C}$ for $96 \mathrm{~h}$ using a freeze dryer (VFD 0030-5085, IlShin, Dongducheon, Korea). The samples were then ground through a cyclone mill (Foss, Hillerød, Denmark) fitted with a $1 \mathrm{~mm}$ screen. The proximate nutrient composition of a sample of each batch was analyzed. Dry matter (DM, \#930.15), crude protein (CP; \#990.03), acid detergent fiber (ADF; \#973.18), ether extract (EE; \#920.39), and ash (\#942.05) were determined as outlined by the AOAC [8]. Samples from all three batches were composited (equal weight, wet basis) and used for the in vitro fermentation study.

\section{Storage stability test}

The BPR sample from the final batch was used to test storage stability. After being thoroughly mixed, BPR $(1.5 \pm 0.03 \mathrm{~kg})$ was sampled in plastic (low-density polyethylene) bags $(22 \times 27 \mathrm{~cm}$; Cleanwrap, Gimhae, Korea). The sample bags were randomly allotted to one of three groups in triplicate: low temperature (LT), room temperature (RT), and high temperature (HT). The LT bags were stored at $4{ }^{\circ} \mathrm{C}$ in a refrigerator $(\mathrm{GC}$ 114HCMP, LG, Seoul, Korea). The RT and HT bags were stored at $20{ }^{\circ} \mathrm{C}$ and $37{ }^{\circ} \mathrm{C}$, respectively, in conventional temperature-controlled incubators (BI-1000 M, JEIO TECH., Daejeon, Korea). After being stored for 0, $2,4,7,14$, and $21 \mathrm{~d}$, samples were taken from each bag and immediately stored at $-80{ }^{\circ} \mathrm{C}$ until further analysis. After being thawed at $20{ }^{\circ} \mathrm{C}$ for $1 \mathrm{~h}$, samples were filtered through 4-layer sterile gauze. The $\mathrm{pH}$ of the filtrate was measured using a $\mathrm{pH}$ meter (EcoMet P25, Istek Inc., Seoul, Korea) and the $\mathrm{NH}_{3}-\mathrm{N}$ concentration was determined [9].

\section{In vitro fermentation}

The composited BPR sample, a commercial concentrate mix (CM) for Korean beef cows (Cargill Agri Purina Inc., Seongnam, Korea), and annual ryegrass straw (ARS) were used for the in vitro ruminal fermentation study. The control diet (CON) comprised $400 \mathrm{~g} / \mathrm{kg} \mathrm{CM}$ and $600 \mathrm{~g} / \mathrm{kg}$ ARS. For the experimental diets, BPR replaced ARS at three levels: $150 \mathrm{~g} / \mathrm{kg}$ (T15), $300 \mathrm{~g} / \mathrm{kg}$ (T30), and $450 \mathrm{~g} / \mathrm{kg}$ (T45); whereas the proportion of 
$\mathrm{CM}$ in the diet remained the same. Consequently, the proportion of BPR in the diet was $90 \mathrm{~g} / \mathrm{kg}, 180 \mathrm{~g} / \mathrm{kg}$, and $270 \mathrm{~g} / \mathrm{kg}$ in T15, T30, and T45, respectively. The nutrient composition of each feed and all experimental diets are presented in Tables 1 and 2 .

Before feeding in the morning, rumen fluid was collected from three cannulated non-lactating Holstein cows that were fed a ration consisting of $550 \mathrm{~g} / \mathrm{kg}$ ARS and $450 \mathrm{~g} / \mathrm{kg} \mathrm{CM}$, twice daily at the Center for Animal Science Research, Chungnam National University, Korea. The study was approved by the Institutional Animal Care and Use Committee (IACUC) at Chungnam National University (IACUC approval No. CNU-00716).

Rumen contents from three cows were mixed in a glass bottle, placed on ice, and immediately transported to the laboratory. The rumen contents were strained through four layers of cheesecloth with glass wool and mixed with $4 \times$ volumes of in vitro buffer solution [10] under strict anaerobic conditions. The rumen fluid/buffer mixture $(50 \mathrm{~mL})$ was transferred into $125 \mathrm{~mL}$ serum bottles containing $0.5 \mathrm{~g}$ of each experimental diet, under conditions of continuous flushing with $\mathrm{O}_{2}$-free $\mathrm{CO}_{2}$ gas. The bottles were sealed with butyl rubber stoppers and aluminum caps, and then incubated for $0,3,6,12,24$, 48 , and $72 \mathrm{~h}$ in an incubator at $39^{\circ} \mathrm{C}$.

After each incubation period, total gas production was measured using a pressure transducer (Sun Bee Instrument Inc., Seoul, Korea), as described by MK Theodorou, BA Williams, MS Dhanoa, AB McAllan and $J$ France [11]. After the $\mathrm{pH}$ of the cultured fluid was measured, it was centrifuged at $21,000 \times \mathrm{g}$ for $10 \mathrm{~min}$ at $4{ }^{\circ} \mathrm{C}$. The supernatant was used for analyses of volatile fatty acids (VFA) and ammonia nitrogen concentration. The remaining undegraded samples and fluid were used to determine in vitro ruminal DM degradability.

\section{Chemical analysis}

The ARS and CM samples were dried at $65{ }^{\circ} \mathrm{C}$ for $72 \mathrm{~h}$ were ground through a cyclone mill (Foss, Hillerød, Denmark) fitted with a 1-mm screen. Further detailed chemical analysis of the ARS, CM and BPR samples was performed, based on the Cornell Net Carbohydrate and Protein System (CNCPS) fractionation scheme [12]. Nutrient composition was analyzed at Cumberland Valley Analytical Services Inc. (MD, USA). DM (\#930.15), crude protein (\#990.03), acid detergent fiber (\#973.18), and ash (\#942.05) were determined as outlined by the AOAC [13], and ether extract (\#2003.05) was determined as described by the AOAC [14]. Crude protein was calculated as 6.25 times nitrogen content, and total nitrogen was measured by the Kjeldahl method, using a Leco FP-528 Nitrogen Combustion Analyzer (Leco, MI, USA). Acid detergent lignin (ADL) and neutral detergent fiber were analyzed using a heat stable amylase and
Table 1 Chemical composition ( $\mathrm{g} / \mathrm{kg}$ DM or as stated) of feeds

\begin{tabular}{|c|c|c|c|}
\hline Item $^{1}$ & $\mathrm{BPR}^{2}$ & Ryegrass straw & Concentrate mix \\
\hline $\mathrm{DM}, \mathrm{g} / \mathrm{kg}$ as fed & 71 & 867 & 864 \\
\hline $\mathrm{OM}$ & 709 & 944 & 938 \\
\hline $\mathrm{CP}$ & 75 & 63 & 149 \\
\hline SOLP & 36 & 20 & 48 \\
\hline NDICP & 8 & 18 & 22 \\
\hline ADICP & 3 & 18 & 15 \\
\hline aNDF & 243 & 754 & 245 \\
\hline ADF & 218 & 520 & 124 \\
\hline ADL & 12 & 134 & 33 \\
\hline Ether extract & 7 & 9 & 40 \\
\hline Ash & 291 & 56 & 62 \\
\hline $\mathrm{Ca}$ & 3 & 5 & 9 \\
\hline$P$ & 2 & 1 & 6 \\
\hline K & 11 & 9 & 11 \\
\hline $\mathrm{Na}$ & 103 & 4 & 4 \\
\hline $\mathrm{Cl}$ & 142 & 7 & 3 \\
\hline S & 3 & 2 & 3 \\
\hline TDN & 527 & 429 & 766 \\
\hline NEm, MJ/kg DM & 4.8 & 3.3 & 7.6 \\
\hline NEg, MJ/kg DM & 2.4 & 1.1 & 5.0 \\
\hline Total carbohydrates & 627 & 872 & 750 \\
\hline NFC & 392 & 136 & 526 \\
\hline
\end{tabular}

Carbohydrate fractions, $\mathrm{g} / \mathrm{kg}$ carbohydrate

$\begin{array}{llll}\text { CA } & 290 & 62 & 115 \\ \text { CB1 } & 16 & 11 & 536 \\ \text { CB2 } & 319 & 83 & 51 \\ \text { CB3 } & 329 & 475 & 194 \\ \text { CC } & 45 & 369 & 104 \\ \text { Protein fractions, g/kg CP } & & \\ \text { PA + B1 } & 480 & 317 & 322 \\ \text { PB2 } & 412 & 402 & 532 \\ \text { PB3 } & 65 & 3 & 48 \\ \text { PC } & 43 & 278 & 98\end{array}$

${ }^{1} D M$ dry matter, $O M$ organic matter, $C P$ crude protein, SOLP soluble $C P, N D I C P$ neutral detergent insoluble $C P, A D I C P$ acid detergent insoluble $C P$, aNDF neutral detergent fiber analyzed using a heat stable amylase and expressed inclusive of residual ash, $A D F$ acid detergent fiber, $A D L$ acid detergent lignin, $T D N$ total digestible nutrients, NEm net energy for maintenance, NEg net energy for growth, NFC non-fiber carbohydrate, CA carbohydrate A fraction, ethanol soluble carbohydrates, $C B 1$ carbohydrate $B 1$ fraction, starch, $C B 2$ carbohydrate B2 fraction, soluble fiber, $C B 3$ carbohydrate $B 3$ fraction, available insoluble fiber, $C C$ carbohydrate $C$ fraction, unavailable carbohydrate, $P A+B 1$ protein $A$ and $B 1$ fractions, soluble $C P, P B 2$ protein $B 2$ fraction, intermediate degradable $C P, P B 3$ protein $B 3$ fraction, slowly degradable fiber-bound $C P, P C$ protein $C$ fraction, unavailable $C P$

${ }^{2}$ By-product of pickled radish. BPR was composited from three batches (equal weight, wet basis) 
Table 2 Chemical composition ( $\mathrm{g} / \mathrm{kg}$ DM or as stated) of in vitro diets

\begin{tabular}{|c|c|c|c|c|}
\hline \multirow[b]{2}{*}{ Item $^{1}$} & \multicolumn{4}{|c|}{ Treatment $^{2}$} \\
\hline & $\mathrm{CON}$ & T15 & T30 & $\mathrm{T} 45$ \\
\hline $\mathrm{DM}, \mathrm{g} / \mathrm{kg}$ as fed & 866 & 871 & 877 & 883 \\
\hline OM & 942 & 920 & 899 & 878 \\
\hline $\mathrm{CP}$ & 97 & 98 & 100 & 101 \\
\hline SOLP & 31 & 33 & 34 & 36 \\
\hline $\mathrm{NDICP}$ & 20 & 19 & 18 & 17 \\
\hline ADICP & 17 & 15 & 14 & 13 \\
\hline aNDF & 550 & 504 & 458 & 412 \\
\hline ADF & 362 & 334 & 307 & 280 \\
\hline ADL & 94 & 83 & 72 & 61 \\
\hline Ether extract & 21 & 21 & 21 & 21 \\
\hline Ash & 58 & 80 & 101 & 122 \\
\hline $\mathrm{Ca}$ & 7 & 7 & 6 & 6 \\
\hline$P$ & 3 & 3 & 3 & 3 \\
\hline K & 10 & 10 & 10 & 10 \\
\hline $\mathrm{Na}$ & 4 & 13 & 22 & 31 \\
\hline $\mathrm{Cl}$ & 5 & 18 & 30 & 42 \\
\hline Salinity & 0 & 21 & 42 & 63 \\
\hline
\end{tabular}

${ }^{1} D M$ dry matter, $O M$ organic matter, $C P$ crude protein, SOLP soluble $C P, N D I C P$ neutral detergent insoluble $C P, A D I C P$ acid detergent insoluble $C P$, aNDF neutral detergent fiber analyzed using a heat stable amylase and expressed inclusive of residual ash, $A D F$ acid detergent fiber, $A D L$ acid detergent lignin ${ }^{2} \mathrm{CON}$ : control diet consisting of $400 \mathrm{~g} / \mathrm{kg}$ concentrate mix and $600 \mathrm{~g} / \mathrm{kg}$ annual ryegrass straw; T15: $90 \mathrm{~g} / \mathrm{kg}$ of annual ryegrass straw (15\%) was substituted with a by-product of pickled radish; T30: $180 \mathrm{~g} / \mathrm{kg}$ of annual ryegrass straw (30 \%) was substituted with a by-product of pickled radish; T45: $270 \mathrm{~g} / \mathrm{kg}$ of annual ryegrass straw $(45 \%)$ was substituted with a by-product of pickled radish

expressed inclusive of residual ash (aNDF) as described by PJ Van Soest, JB Robertson and BA Lewis [15]. Soluble protein (SOLP) was determined as described by $\mathrm{U}$ Krishnamoorthy, TV Muscato, CJ Sniffen and PJ Van Soest [16]. The neutral detergent insoluble crude protein (NDICP) and acid detergent insoluble crude protein (ADICP) in each residue were also determined, as described by G Licitra, TM Hernandez and PJ Van Soest [17]. Ethanol soluble carbohydrate (ESC) and starch contents corrected for free glucose were analyzed as described by MB Hall [18], and mineral contents were determined using appropriate AOAC [19] methods. The total digestible nutrients (TDN), net energy for maintenance (NEm), and net energy for growth (NEg) were estimated based on equations of the NRC [20]. Non-fiber carbohydrates (NFC) were calculated as 100 - ash - EE - CP - (aNDF - NDICP) based on the guidelines of the NRC [20]. Dietary carbohydrate and protein fractions were estimated according to the CNCPS [12] with the following modifications. Sugars and organic acids (CA) were assumed to be equal to ESC; starch was denoted as CB1; and soluble fiber (CB2) was calculated as
NFC - CA - CB1. Available NDF (CB3) was estimated by the equation (aNDF - NDICP) - (2.4 $\times$ ADL); and unavailable carbohydrate $(\mathrm{CC})$ was estimated as $2.4 \times \mathrm{ADL}$. For protein fractions, the sum of non-protein nitrogen and soluble true protein (PA $+\mathrm{B} 1)$ was assumed to be equal to SOLP. Intermediate degradable CP (PB2) was estimated by the equation 100 - NDICP - SOLP. Slowly degradable fiber-bound $\mathrm{CP}$ (PB3) was estimated by the equation NDICP - ADICP; and unavailable CP (PC) was assumed to be equal to ADICP. All carbohydrate and protein fractions were expressed as $\mathrm{g} / \mathrm{kg}$ of total carbohydrate and $\mathrm{CP}$, respectively. Results of the analysis are presented in Table 1.

The $\mathrm{NH}_{3}-\mathrm{N}$ concentration was determined according to the methods of AL Chaney and EP Marbach [21]. Following re-centrifugation of BPR filtrate or in vitro cultured fluid at $21,000 \times \mathrm{g}$ for $15 \mathrm{~min}, 20 \mu \mathrm{L}$ of the supernatant was mixed with $1 \mathrm{~mL}$ of phenol color reagent and $1 \mathrm{~mL}$ of alkali-hypochlorite reagent. The mixture was then incubated in a water bath for $15 \mathrm{~min}$ at $37{ }^{\circ} \mathrm{C}$. After being mixed with $8 \mathrm{~mL}$ of distilled water, the optical density of the mixture was measured at $630 \mathrm{~nm}$, using a spectrophotometer (UV-1800, Shimadzu, Japan).

The VFA concentration was determined as described by ES Erwin, GJ Marco and EM Emery [9]. In vitro cultured fluid $(1 \mathrm{~mL})$ was mixed with $0.2 \mathrm{~mL}$ of metaphosphoric acid $(250 \mathrm{~g} / \mathrm{L})$ and kept at $4{ }^{\circ} \mathrm{C}$ for $30 \mathrm{~min}$. Following centrifugation of the mixture at $21,000 \times \mathrm{g}$ for $10 \mathrm{~min}$ at $20{ }^{\circ} \mathrm{C}$, the supernatant was injected into a gas chromatograph (HP 6890, Hewlett-Packard Co., CA, USA) equipped with a flame ionization detector (FID) and capillary column ( ukol $^{\mathrm{Tm}}$ Fused silica capillary column $30 \mathrm{~m} \times 0.25 \mathrm{~mm} \times 0.2 \mu \mathrm{m}$, Supelco Inc., PA, USA). The temperatures of the oven, injector, and detector were $90{ }^{\circ} \mathrm{C}-180{ }^{\circ} \mathrm{C}, 185{ }^{\circ} \mathrm{C}$, and $210{ }^{\circ} \mathrm{C}$, respectively. Nitrogen was used as the carrier gas at a flow rate of $40 \mathrm{~mL} / \mathrm{min}$.

\section{Statistical analysis}

All data were analyzed using the MIXED procedure of SAS [22] with an appropriate statistical model for each analysis. In addition, comparisons were made between linear and quadratic functions among treatments for analysis of in vitro fermentation. Differences among treatments were also compared with the Tukey's range test if there was a significant overall treatment effect. For the test of storage stability, repeated measures analysis was used to evaluate the effects of storage temperature. The interaction between treatment (i.e., different storage temperatures) and duration was of particular interest. Two-way ANOVA with fixed effects of hour of incubation, treatment, and interactions between those factors was used to analyze the in vitro ruminal 
Table 3 Variation in nutrient composition (g/kg DM or as stated) of by-product of pickled radish (BPR)

\begin{tabular}{|c|c|c|c|c|c|c|}
\hline \multirow[b]{2}{*}{ Item ${ }^{1}$} & \multicolumn{3}{|c|}{ BPR samples ${ }^{2}$} & \multirow[b]{2}{*}{ Mean } & \multirow[b]{2}{*}{ SD } & \multirow[b]{2}{*}{$\mathrm{CV}$} \\
\hline & Month 1 & Month 2 & Month 3 & & & \\
\hline $\mathrm{DM}^{3}, \mathrm{~g} / \mathrm{kg}$ as fed & 99.6 & 138.2 & 168.7 & 135.5 & 28.30 & 20.89 \\
\hline OM & 666.8 & 735.0 & 739.3 & 713.7 & 33.21 & 4.65 \\
\hline$C P$ & 60.5 & 67.3 & 77.4 & 68.4 & 6.92 & 10.11 \\
\hline aNDF & 216.3 & 369.8 & 365.3 & 317.2 & 71.32 & 22.49 \\
\hline ADF & 170.6 & 312.7 & 297.5 & 260.3 & 63.71 & 24.48 \\
\hline Ether extract & 7.8 & 10.7 & 17.5 & 12.0 & 4.05 & 33.83 \\
\hline Ash & 333.2 & 265.0 & 260.7 & 286.3 & 63.71 & 24.48 \\
\hline $\mathrm{Ca}$ & 4 & 3 & 3 & 3 & 0.61 & 18.08 \\
\hline$P$ & 2 & 1 & 1 & 1 & 0.33 & 23.94 \\
\hline K & 16 & 9 & 9 & 11.3 & 3.40 & 30.01 \\
\hline Salinity & 260 & 151 & 210 & 207.2 & 44.58 & 21.51 \\
\hline
\end{tabular}

'DM dry matter, OM organic matter, $C P$ crude protein, aNDF neutral detergent fiber analyzed using a heat stable amylase and expressed inclusive of residual ash, $A D F$ acid detergent fiber

${ }^{2}$ Samples were obtained three times on April 22, May 27, and July 6, 2015 from a pickled radish manufacturer (llga, Sejong, Korea)

${ }^{3}$ Dry matter content was based on the amount of residue after freeze-drying

fermentation characteristics. Linear and quadratic effects of the inclusion rate of BPR were tested using contrasts. Statistical significance was considered at $P<0.05$, and a trend was determined at $0.05 \leq P<0.1$.

\section{Results and discussion}

The use of by-products of food processing has been of great interest in the livestock industry, particularly as it relates to reducing feed-related costs [23]. A significant amount of BPR is continuously being produced as the market for pickled radish keeps growing in Korea; however, most of it is wasted [5]. There is therefore solid justification to recycle BPR as a feed source for ruminant animals that have evolutionarily adapted to use low digestible nutrients efficiently in processes facilitated by symbiosis with rumen microbes [24].

To the best of our knowledge, this is the first study to explore the potential of BPR as an animal feed resource.

\section{Nutrient composition of the BPR}

The BPR had high moisture content (more than $800 \mathrm{~g} /$ $\mathrm{kg}$ on an as fed basis, Table 1). Owing to a high level of ash (mostly sodium [103 g/kg DM] and chloride [142 g/ $\mathrm{kg} \mathrm{DM}$ ], the organic matter content was $709 \mathrm{~g} / \mathrm{kg} \mathrm{DM}$, which is lower than that of common feedstuffs (i.e., ARS and $\mathrm{CM}$ ). On a dry matter basis, the $\mathrm{CP}$ and EE levels in BPR were $75 \mathrm{~g} / \mathrm{kg}$ and $7 \mathrm{~g} / \mathrm{kg}$, respectively, which is comparable with those in ARS, whereas, the fiber content of BPR was just as low as that of CM. Cellulose comprised $85 \%$ of the fiber content of BPR ([ADF ADL]/NDF, Table 1). The TDN of BPR was $527 \mathrm{~g} / \mathrm{kg}$ $\mathrm{DM}$, which is between those of ARS and CM. The major portion of digestible nutrients was carbohydrate: $88 \%$ of OM was carbohydrate and $62.5 \%$ of total carbohydrate was NFC. NFC comprised mainly water-soluble carbohydrates (CA) and soluble fiber (CB2). Most of the CC represented a small proportion of aNDF (Table 1). A large proportion of CP in BPR was soluble (48\%) and only a small amount was fiber-bound (6.5\%), or unavailable $(4.3 \%)$ (Table 1$)$. Besides sodium and chloride, the levels of other macro- or micro-minerals were low. Toxic micro-minerals (i.e., $\mathrm{Hg}, \mathrm{Cr}, \mathrm{Pb}, \mathrm{Cd}$, and $\mathrm{As}$ ) were not detected in BPR.

A notable characteristic of BPR was its relatively high sodium chloride $(\mathrm{NaCl})$ content. Ruminant animals are able to excrete large quantities of $\mathrm{NaCl}[25,26]$. Thus, they are tolerant of higher levels and increased intake of $\mathrm{NaCl}$

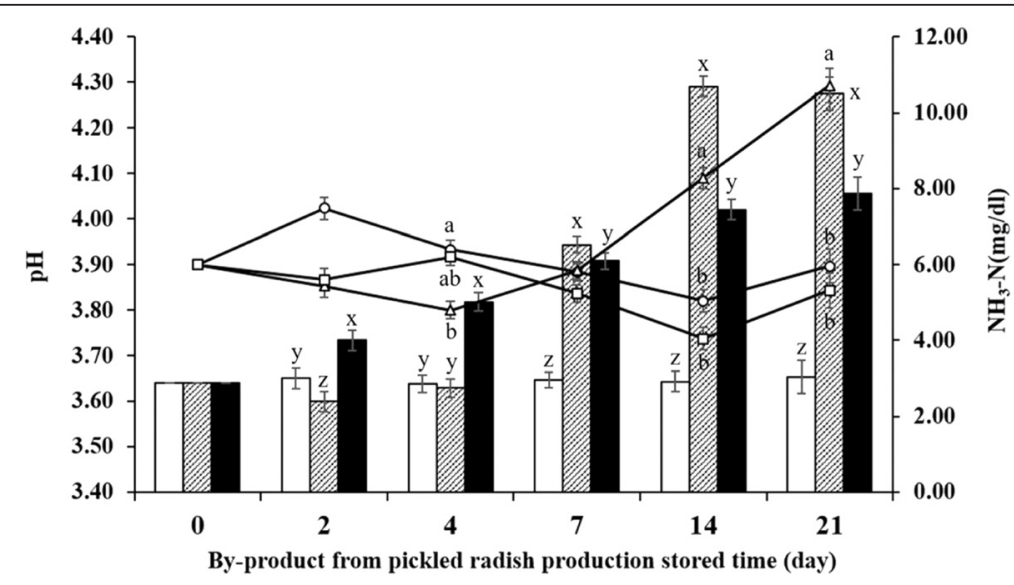

Fig. 1 Changes in $\mathrm{pH}$ and ammonia nitrogen $\left(\mathrm{NH}_{3}-\mathrm{N}\right)$ concentration during storage at three different temperatures. The $\mathrm{pH}$ at low $\left(4^{\circ} \mathrm{C}\right.$, o $)$; room $\left(20^{\circ} \mathrm{C}, \Delta\right)$; and high $\left(37^{\circ} \mathrm{C}\right.$, 口) temperatures and the $\mathrm{NH}_{3}-\mathrm{N}$ concentrations at low $\left(4^{\circ} \mathrm{C}\right.$, open bar); room $\left(20^{\circ} \mathrm{C}\right.$, shaded bar); and high $\left(37^{\circ} \mathrm{C}\right.$, solid bar) temperatures. Each error bar represents the standard error of the mean temperature on each day. ${ }^{\mathrm{a}-\mathrm{c}}$ Means of $\mathrm{pH}$ that do not have common superscript differ $(P<0.05)$. ${ }^{\mathrm{x}-\mathrm{z}}$ Means of $\mathrm{NH}_{3}-\mathrm{N}$ concentration that do not have common superscript differ $(P<0.05)$ 
Table 4 The $\mathrm{pH}$ and concentration of $\mathrm{NH}_{3}-\mathrm{N}$ and VFA after in vitro ruminal fermentation

\begin{tabular}{|c|c|c|c|c|c|c|c|c|}
\hline \multirow[b]{2}{*}{ Item } & \multicolumn{4}{|c|}{ Treatment $^{1}$} & \multirow[b]{2}{*}{ SEM } & \multicolumn{3}{|c|}{$P$-value } \\
\hline & CON & T15 & T30 & T45 & & Mean & Linear & Quadratic \\
\hline \multicolumn{9}{|l|}{$\mathrm{pH}$} \\
\hline $3 \mathrm{~h}$ & $6.58^{\mathrm{a}}$ & $6.56^{\mathrm{ab}}$ & $6.55^{\mathrm{b}}$ & $6.55^{\mathrm{b}}$ & 0.004 & 0.01 & $<0.01$ & 0.08 \\
\hline $6 \mathrm{~h}$ & $6.56^{\mathrm{a}}$ & $6.54^{\mathrm{ab}}$ & $6.54^{\mathrm{bc}}$ & $6.52^{c}$ & 0.003 & $<0.01$ & $<0.01$ & 0.35 \\
\hline $12 \mathrm{~h}$ & $6.51^{\mathrm{a}}$ & $6.48^{\mathrm{b}}$ & $6.45^{c}$ & $6.43^{d}$ & 0.003 & $<0.01$ & $<0.01$ & 0.63 \\
\hline $24 \mathrm{~h}$ & 6.44 & 6.43 & 6.41 & 6.41 & 0.006 & 0.02 & $<0.01$ & 0.81 \\
\hline $48 \mathrm{~h}$ & $6.39^{\mathrm{a}}$ & $6.38^{\mathrm{ab}}$ & $6.36^{\mathrm{b}}$ & $6.27^{\mathrm{b}}$ & 0.005 & 0.02 & $<0.01$ & 0.09 \\
\hline $72 \mathrm{~h}$ & 6.40 & 6.40 & 6.40 & 6.40 & 0.005 & 0.75 & 0.89 & 0.75 \\
\hline \multicolumn{9}{|c|}{$\mathrm{NH}_{3}-\mathrm{N}(\mathrm{mg} / \mathrm{dL})$} \\
\hline $3 \mathrm{~h}$ & 10.97 & 10.02 & 9.41 & 8.80 & 0.662 & 0.20 & 0.04 & 0.81 \\
\hline $6 \mathrm{~h}$ & $12.95^{\mathrm{a}}$ & $12.76^{\mathrm{ab}}$ & $12.24^{\mathrm{ab}}$ & $11.80^{b}$ & 0.243 & 0.04 & $<0.01$ & 0.63 \\
\hline $12 \mathrm{~h}$ & 12.95 & 12.18 & 11.27 & 11.36 & 0.713 & 0.36 & 0.11 & 0.56 \\
\hline $24 \mathrm{~h}$ & 15.22 & 15.32 & 16.15 & 15.49 & 0.504 & 0.59 & 0.49 & 0.48 \\
\hline $48 \mathrm{~h}$ & $20.69^{b}$ & $22.54^{\mathrm{a}}$ & $22.28^{a}$ & $23.77^{\mathrm{a}}$ & 0.624 & 0.05 & 0.01 & 0.78 \\
\hline $72 \mathrm{~h}$ & $27.12^{b}$ & $26.68^{b}$ & $29.53^{a}$ & $30.40^{\mathrm{a}}$ & 0.352 & $<0.01$ & $<0.01$ & 0.10 \\
\hline \multicolumn{9}{|c|}{ Total VFA (mM) } \\
\hline $3 \mathrm{~h}$ & 19.73 & 20.24 & 20.57 & 21.16 & 0.491 & 0.29 & 0.07 & 0.94 \\
\hline $6 \mathrm{~h}$ & $23.32^{b}$ & $24.58^{\mathrm{ab}}$ & $28.20^{\mathrm{a}}$ & $27.85^{\mathrm{a}}$ & 0.872 & $<0.01$ & $<0.01$ & 0.38 \\
\hline $12 \mathrm{~h}$ & $31.54^{c}$ & $34.39^{b c}$ & $36.90^{\mathrm{ab}}$ & $38.11^{\mathrm{a}}$ & 0.668 & $<0.01$ & $<0.01$ & 0.25 \\
\hline $24 \mathrm{~h}$ & 40.11 & 46.47 & 46.97 & 43.57 & 1.751 & 0.08 & 0.20 & 0.02 \\
\hline $48 \mathrm{~h}$ & 51.08 & 53.99 & 53.61 & 51.93 & 2.255 & 0.77 & 0.83 & 0.34 \\
\hline $72 \mathrm{~h}$ & $53.14^{b}$ & $55.06^{b}$ & $58.42^{\mathrm{a}}$ & $60.17^{a}$ & 0.570 & $<0.01$ & $<0.01$ & 0.89 \\
\hline \multicolumn{9}{|l|}{ A:P ratio } \\
\hline $3 \mathrm{~h}$ & $4.07^{\mathrm{a}}$ & $3.97^{b}$ & $3.87^{c}$ & $3.83^{c}$ & 0.017 & $<0.01$ & $<0.01$ & 0.16 \\
\hline $6 \mathrm{~h}$ & $4.07^{\mathrm{a}}$ & $4.06^{\mathrm{a}}$ & $3.95^{\mathrm{b}}$ & $3.96^{\mathrm{b}}$ & 0.014 & $<0.01$ & $<0.01$ & 0.46 \\
\hline $12 \mathrm{~h}$ & $4.15^{\mathrm{a}}$ & $4.13^{\mathrm{a}}$ & $3.95^{b}$ & $3.94^{b}$ & 0.013 & $<0.01$ & $<0.01$ & 0.60 \\
\hline $24 \mathrm{~h}$ & $3.77^{c}$ & $3.83^{b c}$ & $3.88^{\mathrm{ab}}$ & $3.96^{\mathrm{a}}$ & 0.019 & $<0.01$ & $<0.01$ & 0.58 \\
\hline $48 \mathrm{~h}$ & $3.64^{c}$ & $3.72^{b c}$ & $3.79^{\mathrm{ab}}$ & $3.85^{\mathrm{a}}$ & 0.023 & $<0.01$ & $<0.01$ & 0.52 \\
\hline $72 \mathrm{~h}$ & $3.60^{c}$ & $3.67^{b}$ & $3.73^{\mathrm{a}}$ & $3.77^{\mathrm{a}}$ & 0.010 & $<0.01$ & $<0.01$ & 0.15 \\
\hline
\end{tabular}

${ }^{1} \mathrm{CON}$ : Control diet consisting of $400 \mathrm{~g} / \mathrm{kg}$ concentrate mix and $600 \mathrm{~g} / \mathrm{kg}$ annual ryegrass straw; $115: 90 \mathrm{~g} / \mathrm{kg}$ of annual ryegrass straw (15 \%) was substituted with a by-product of pickled radish; T30: $180 \mathrm{~g} / \mathrm{kg}$ of annual ryegrass straw (30 \%) was substituted with a by-product of pickled radish; T45: $270 \mathrm{~g} / \mathrm{kg}$ of annual ryegrass straw (45\%) was substituted with a by-product of pickled radish

${ }^{\mathrm{a}-\mathrm{d}}$ Means that do not have common superscript differ $(P<0.05)$

might not pose a problem if sufficient drinking water is provided [27, 28]. However, several studies have reported that high levels of $\mathrm{NaCl}$ negatively affects the growth of young sheep [29] and reduces growth rate and wool production in sheep, particularly when $\mathrm{CP}$ is also supplemented [30]. When balancing a ration with BPR, this higher $\mathrm{NaCl}$ content therefore needs to be considered.

The nutrient composition of BPR varied among the production batches. The coefficient of variation (CV) of nutrient contents ranged from 4.65 to $33.83 \%$ (Table 3). The smallest CV was observed in OM, and the largest, in EE. The variation in $\mathrm{CP}$ content was relatively small (10.11 \%); however, CVs in NDF, ADF, and ash were relatively large $(22.49,24.48$, and $24.48 \%$, respectively).
Among minerals, the CVs of $\mathrm{Ca}, \mathrm{P}$, and $\mathrm{K}$ were 18.08 , 23.94, and $30.01 \%$, respectively. This indicated that variation among the mineral contents was also large.

Nutrient composition may vary according to the time and method of production. This can be an important issue when considering the use of food by-products as animal feeds [31]. Nevertheless, the variations in nutrient composition were within the range of wet by-products commonly used as feed ingredients. When the data provided by Dairy One Inc. [32] were analyzed, the average CVs among wet by-products were 33.0, 41.8, 43.8, 79.7, and $44.1 \%$ for $\mathrm{CP}, \mathrm{NDF}, \mathrm{ADF}, \mathrm{EE}$, and ash, respectively; this feed composition library accessed in March, 2016. The wet by-products included apple pomace, beet pulp, 
Table 5 Effect of by-product of pickled radish on in vitro ruminal DM degradability (IVDMD, g/kg DM)

\begin{tabular}{|c|c|c|c|c|c|c|c|c|}
\hline \multirow[b]{2}{*}{ Time } & \multicolumn{4}{|c|}{ Treatment $^{1}$} & \multirow[b]{2}{*}{ SEM } & \multicolumn{3}{|c|}{$P$-value } \\
\hline & CON & T15 & T30 & T45 & & Mean & Linear & Quadratic \\
\hline $6 \mathrm{~h}$ & $63.4^{c}$ & $75.4^{\mathrm{bc}}$ & $108.1^{b}$ & $204.9^{a}$ & 9.05 & $<0.01$ & $<0.01$ & $<0.01$ \\
\hline $12 \mathrm{~h}$ & $143.6^{c}$ & $180.0^{b c}$ & $234.2^{b}$ & $321.7^{a}$ & 13.50 & $<0.01$ & $<0.01$ & 0.09 \\
\hline $24 \mathrm{~h}$ & $312.8^{c}$ & $336.3^{c}$ & $381.1^{\mathrm{b}}$ & $492.3^{a}$ & 4.39 & $<0.01$ & $<0.01$ & $<0.01$ \\
\hline $48 \mathrm{~h}$ & $477.3^{d}$ & $491.7^{b}$ & $534.9^{b}$ & $630.4^{a}$ & 13.72 & $<0.01$ & $<0.01$ & 0.02 \\
\hline $72 \mathrm{~h}$ & $556.0^{\mathrm{a}}$ & $577.9^{b c}$ & $589.8^{b}$ & $682.7^{\mathrm{a}}$ & 5.22 & $<0.01$ & $<0.01$ & $<0.01$ \\
\hline
\end{tabular}

${ }^{1} \mathrm{CON}$ : Control diet consisting of $400 \mathrm{~g} / \mathrm{kg}$ concentrate mix and $600 \mathrm{~g} / \mathrm{kg}$ annual ryegrass straw; T15: $90 \mathrm{~g} / \mathrm{kg}$ of annual ryegrass straw (15\%) was substituted with a by-product of pickled radish; $T 30: 180 \mathrm{~g} / \mathrm{kg}$ of annual ryegrass straw (30 \%) was substituted with a by-product of pickled radish; T45: $270 \mathrm{~g} / \mathrm{kg}$ of annual ryegrass straw $(45 \%)$ was substituted with a by-product of pickled radish

${ }^{a-c}$ Means that do not have common superscript differ $(P<0.05)$

carrot, citrus pulp, other fruit byproducts, and grape pomace, etc. High variability is commonly observed in the nutrient composition of feedstuffs; thus, the variations observed in BPR might not pose a major problem.

\section{Storage stability}

Significant effects of temperature, storage duration, and the interactions between those two factors were noted on $\mathrm{pH}$ and $\mathrm{NH}_{3}-\mathrm{N}$ concentration $(P<0.05$, Fig. 1$)$. The RT group yielded a significantly higher $\mathrm{pH}$ on days 14 and 21 in comparison to the other treatments $(P<0.05)$. The $\mathrm{pH}$ of the RT group declined until day 4 , but increased thereafter. On the other hand, the $\mathrm{pH}$ of the LT group increased on day 2, was subsequently reduced until day 14, and increased again on day 21. The $\mathrm{pH}$ trend of the HT group was similar to that of the LT group. However, the highest $\mathrm{pH}$ in the HT group was observed on day 4, whereas that in the LT group, on day 2.

The $\mathrm{NH}_{3}-\mathrm{N}$ concentration in the LT group was not altered during storage; however, that in the RT and HT groups was significantly increased during storage $(P<0.05$, Fig. 1). A sudden increase in $\mathrm{NH}_{3}-\mathrm{N}$ concentration was observed in the RT group on day 7. The $\mathrm{NH}_{3}-\mathrm{N}$ concentration in the RT group was significantly higher on days 14 and 21 in comparison to other groups $(P<0.01)$. The HT group yielded significantly higher $\mathrm{NH}_{3}-\mathrm{N}$ concentrations on days 2 and $4(P<0.01)$ that constantly increased thereafter, for the duration of storage.

Since BPR contains a large amount of moisture (more than $800 \mathrm{~g} / \mathrm{kg}$ on an as fed basis), storage stability was an important consideration. Handling, storage, and feeding challenges can occur if a feed ingredient has a moisture level that is higher than $200 \mathrm{~g} / \mathrm{kg}$ on an as fed basis [33]. One of the major issues with high moisture contents in food-by products is the potential for spoilage during storage and transport [4]. Since the survival of microbes depends on moisture levels [34], a high moisture content can cause spoilage, which leads to bio-security risks [3].

The results of the storage stability test revealed that despite its high moisture content, storage of BPR even at room temperature might not cause spoilage for $4 \mathrm{~d}$ and possibly later. If refrigerated, spoilage of BPR can be deferred until $21 \mathrm{~d}$ and possibly later. Owing to its high moisture content, BPR can be used as a feed ingredient in a total mixed ration (TMR). If this is the case, the possibility of spoilage can be further reduced by fermentation of the TMR [35].

\section{In vitro fermentation}

As the level of substitution of ARS by BPR increased, in vitro ruminal $\mathrm{pH}$ was significantly reduced in a linear manner at each time point from 3 to $48 \mathrm{~h}(P<0.01$, Table 4). For the first $12 \mathrm{~h}$ of in vitro fermentation, $\mathrm{NH}_{3}-\mathrm{N}$ concentrations declined in a linear manner, as the proportion of BPR increased (Table 4). The $\mathrm{NH}_{3}-\mathrm{N}$ concentration of $\mathrm{CON}$ was highest at $12 \mathrm{~h}$. The $\mathrm{NH}_{3}-\mathrm{N}$ concentrations at 12 and $24 \mathrm{~h}$ did not differ significantly among treatments. However, at 48 and $72 \mathrm{~h}, \mathrm{NH}_{3}-\mathrm{N}$ concentrations increased in a linear manner, as inclusion of BPR increased. The $\mathrm{NH}_{3}-\mathrm{N}$ concentration of $\mathrm{T} 45$ was significantly higher than that of CON $(P<0.05)$. As BPR inclusion levels increased, total VFA increased in a linear manner up to $12 \mathrm{~h}$ and at $72 \mathrm{~h}$ (Table 4). At 6, 12, and $72 \mathrm{~h}$, total VFA concentrations were significantly higher

Table 6 Effect of by-products of pickled radish on in vitro ruminal total gas production $(\mathrm{mL})$

\begin{tabular}{|c|c|c|c|c|c|c|c|c|}
\hline \multirow[b]{2}{*}{ Time } & \multicolumn{4}{|c|}{ Treatment $^{1}$} & \multirow[b]{2}{*}{ SEM } & \multicolumn{3}{|c|}{$P$-value } \\
\hline & CON & T15 & T30 & T45 & & $\overline{\text { Mean }}$ & Linear & Quadratic \\
\hline $3 \mathrm{~h}$ & 24.97 & 26.23 & 27.17 & 27.19 & 0.515 & 0.05 & 0.01 & 0.26 \\
\hline $6 \mathrm{~h}$ & $45.91^{b}$ & $48.84^{\mathrm{ab}}$ & $51.81^{\mathrm{a}}$ & $53.70^{a}$ & 1.184 & $<0.01$ & $<0.01$ & 0.67 \\
\hline $12 \mathrm{~h}$ & $70.17^{c}$ & $74.02^{b}$ & $86.14^{\mathrm{a}}$ & $86.09^{a}$ & 0.749 & $<0.01$ & $<0.01$ & 0.03 \\
\hline $24 \mathrm{~h}$ & $101.03^{c}$ & $106.71^{b c}$ & $115.02^{\mathrm{ab}}$ & $118.69^{a}$ & 1.941 & $<0.01$ & $<0.01$ & 0.62 \\
\hline $48 \mathrm{~h}$ & $116.75^{\mathrm{b}}$ & $132.23^{\mathrm{ab}}$ & $137.18^{\mathrm{a}}$ & $143.15^{\mathrm{a}}$ & 4.467 & 0.02 & $<0.01$ & 0.32 \\
\hline $72 \mathrm{~h}$ & $146.02^{b}$ & $150.49^{\mathrm{ab}}$ & $152.63^{\mathrm{ab}}$ & $158.54^{a}$ & 0.345 & 0.03 & $<0.01$ & 0.77 \\
\hline
\end{tabular}

${ }^{1} \mathrm{CON}$ : Control diet consisting of $400 \mathrm{~g} / \mathrm{kg}$ concentrate mix and $600 \mathrm{~g} / \mathrm{kg}$ annual ryegrass straw; T15: $90 \mathrm{~g} / \mathrm{kg}$ of annual ryegrass straw (15\%) was substituted with a by-product of pickled radish; T30: $180 \mathrm{~g} / \mathrm{kg}$ of annual ryegrass straw (30 \%) was substituted with a by-product of pickled radish; T45: $270 \mathrm{~g} / \mathrm{kg}$ of annual ryegrass straw (45\%) was substituted with a by-product of pickled radish

${ }^{a-c}$ Means that do not have common superscript differ $(P<0.05)$ 
in $\mathrm{T} 45$ than in $\mathrm{CON}(\mathrm{P}<0.05)$. The acetate/propionate $(\mathrm{A} / \mathrm{P})$ ratio was higher in CON than in T45 $(P<0.01)$ for up to $12 \mathrm{~h}$ of in vitro ruminal fermentation; however, the A/P ratio of $\mathrm{T} 45$ became significantly higher than that of CON after $24 \mathrm{~h}(P<0.01$, Table 4$)$. For up to $12 \mathrm{~h}$, the $\mathrm{A} / \mathrm{P}$ ratio declined in a linear manner, as BPR inclusion levels increased; however, after $24 \mathrm{~h}$, this relationship became a linear decline with increasing levels of BPR.

Significant linear and quadratic relationships were observed in in vitro ruminal DM degradability (IVDMD), with increasing BPR inclusion levels at most time points (Table 5). The IVDMD of T15 was not significantly different from that of $\mathrm{CON}$ at all time points; however, the IVDMD of T30 was greater than that of CON throughout the incubation period, except at $48 \mathrm{~h}$. The IVDMD of T45 was significantly higher than that of the other treatments at all time points $(P<0.05)$. The IVDMD did not differ significantly between T15 and T30, except at $24 \mathrm{~h}$. The total gas production significantly increased in a linear manner throughout the process of in vitro fermentation, as BPR inclusion levels increased (Table 6). No significant differences were noted in total gas production between T30 and T45 at any time point.

In vitro ruminal incubation using strained rumen fluid is a very useful technique to assess ruminal fermentation in vivo [36,37]. The VFA concentrations of the cultured fluid, DM degradability, and total gas production after in vitro ruminal fermentation can be good indicators to evaluate the nutritional value of novel feed ingredients [38]. The present study demonstrated that substitution of ARS with BPR improves ruminal fermentation, as evidenced by increased VFA concentration, DM degradability, and total gas production. Since the A/P ratio did not decline with a longer incubation time, the acid load from rapid fermentation that could lead to metabolic disorders [39] might not pose a problem with BPR supplementation. This could be attributed to the fact that approximately $65 \%$ of the carbohydrate content of BPR is soluble fiber and degradable NDF (the sum of CB2 and CB3 fractions, Table 1), both of which are rapidly fermented in the rumen without the production of lactic acid [40]. Moreover, the high $\mathrm{NaCl}$ content in BPR did not adversely affect microbial fermentation in the rumen. Based on the results of the in vitro fermentation study, BPR can be successfully used as a feed ingredient in a ruminant diet.

\section{Conclusion}

In conclusion, the major portion of nutrients in BPR comprises soluble or degradable fiber that can be easily fermented in the rumen without adverse effects, to provide energy to ruminant animals. Although its high $\mathrm{NaCl}$ content needs to be considered when formulating a ration, BPR can be effectively used as a feed ingredient in a ruminant diet, particularly if included as one component of a TMR.

Acknowledgments

\section{Funding}

This study was supported by the Bioindustry Technology Development Program (313020-04-2-HD020), Ministry of Agriculture, Food and Rural Affairs, Republic of Korea.

\section{Availability of data and materials}

Not applicable.

\section{Authors' contributions}

Seoyoung Jeon designed and performed the experiment and wrote the manuscripts. Keun-Nam Sohn prepared the samples and designed the experiments. Seongwon Seo supervised the study, performed statistical analysis and wrote the manuscript. All authors read and approved the final manuscript.

\section{Authors' information}

Division of Animal \& Dairy Sciences, Chungnam National University, 99 Daehak-ro, Yuseong-gu, Daejeon, Republic of Korea.

\section{Competing interests}

The authors declare that they have no competing interests.

\section{Consent for publication}

Not applicable.

\section{Ethics approval and consent to participate}

The study was approved by the Institutional Animal Care and Use Committee (IACUC) at Chungnam National University. The IACUC approval number is CNU-00716

Received: 1 May 2016 Accepted: 6 August 2016

Published online: 16 September 2016

\section{References}

1. Mirabella N, Castellani V, Sala S. Current options for the valorization of food manufacturing waste: a review. J Clean Prod. 2014;65:28-41.

2. Kroyer GT. Impact of food processing on the environment - an overview. Lebensm Wiss Technol. 1995;28(6):547-52.

3. Van Dyk JS, Gama R, Morrison D, Swart S, Pletschke BI. Food processing waste: problems, current management and prospects for utilisation of the lignocellulose component through enzyme synergistic degradation. Renew Sust Energ Rev. 2013;26:521-31.

4. Laufenberg G, Kunz B, Nystroem M. Transformation of vegetable waste into value added products: (A) the upgrading concept; (B) practical implementations. Bioresource Technol. 2003;87(2):167-98.

5. Jung UH, Oh JH, Kim YG, Ahn CH, Lee KS, Choi SR, Lim YP, Park SH, Choi KY, Lee YB. Development of highly uniform variety for processing using SSR markers in radish (Raphanus sativus L). J Plant Biotechnol. 2014:41:56-63.

6. Rural development administration. Standard tables of feed composition in Korea. Korea: National institute of animal science; 2007.

7. Cho EH, Choi AR, Choi SJ, Kim SY, Lee GS, Lee SS, Chae HJ. a-amylase activity of radish and stability in processing. J Korean Soc Food Sci Nutr. 2009;38(6):812-5.

8. AOAC Official methods of analysis of AOAC international. 1997

9. Erwin ES, Marco GJ, Emery EM. Volatile fatty acid analyses of blood and rumen fluid by gas chromatography. J Dairy Sci. 1961;44(9):1768-71.

10. Goering HK, Van Soest PJ. Forage fiber analyses (apparatus, reagents, procedures, and some applications). USA: U.S. Agricultural Research Service; 1970.

11. Theodorou MK, Williams BA, Dhanoa MS, McAllan AB, France J. A simple gas production method using a pressure transducer to determine the fermentation kinetics of ruminant feeds. Anim Feed Sci Tech. 1994:48(3):185-97.

12. Fox DG, Tedeschi LO, Tylutki TP, Russell JB, Van Amburgh ME, Chase LE, Pell AN, Overton TR. The Cornell Net Carbohydrate and Protein System model for evaluating herd nutrition and nutrient excretion. Anim Feed Sci Tech. 2004:112(1):29-78.

13. AOAC. Official methods of analysis of AOAC international. 2005 
14. AOAC. Official methods of analysis of AOAC international. 2006.

15. Van Soest PJ, Robertson JB, Lewis BA. Methods for dietary fiber, neutral detergent fiber, and nonstarch polysaccharides in relation to animal nutrition. J Dairy Sci. 1991;74(10):3583-97.

16. Krishnamoorthy U, Muscato TV, Sniffen CJ, Van Soest PJ. Nitrogen fractions in selected feedstuffs. J Dairy Sci. 1982;65(2):217-25.

17. Licitra G, Hernandez TM, Van Soest PJ. Standardization of procedures for nitrogen fractionation of ruminant feeds. Anim Feed Sci Tech. 1996;57(4):347-58.

18. Hall MB. Analysis of starch, including maltooligosaccharides, in animal feeds: A comparison of methods and a recommended method for AOAC collaborative study. J AOAC Int. 2009:92(1):42-9.

19. AOAC. Official methods of analysis of AOAC international. 2000.

20. NRC. Nutrient requirements of dairy cattle. Washington, D.C.: National Academic Press; 2001.

21. Chaney AL, Marbach EP. Modified reagents for determination of urea and ammonia. Clin Chem. 1962;8(2):130-2.

22. Institute SAS. SAS user's quide: statistics. 9th ed. Cary: SAS Inst. Inc.; 2014

23. Seo J, Jung JK, Seo S. Evaluation of nutritional and economic feed values of spent coffee grounds and Artemisia princeps residues as a ruminant feed using in vitro ruminal fermentation. Peer J. 2015;3:e1343.

24. Hungate RE. The rumen and its microbes. USA: Academic; 1966.

25. Godwin IR, Williams VJ. Effects of intraruminal sodium chloride infusion on rumen and renal nitrogen and electrolyte dynamics in sheep. Brit J Nutr. 1986;56(2):379-94.

26. Moseley G. Effects of variation in herbage sodium levels and salt supplementation on the nutritive value of perennial ryegrass for sheep. Grass Forage Sci. 1980;35(2):105-13.

27. Morris JG. Assessment of sodium requirements of grazing beef cattle: A review. J Anim Sci. 1980;50(1):145-52.

28. NRC. Mineral tolerance of domestic animals. Washington, D.C.: National Academic Press; 1980.

29. De Waal HO, Engels EAN, Van der Merwe FJ, Biel LC. Supplementing sheep with protein and phosphorus on native pasture of the central Orange Free State. 2. Feed intake, mass changes and wool production. S Afr J Anim Sci. 1981:17(3):217-27.

30. De Waal HO, Baard MA, Engels EAN. Effects of sodium chloride on sheep. 1. Diet composition, body mass changes and wool production of young Merino wethers grazing native pasture. S Afr J Anim Sci. 1989;19:27-33.

31. Mirzaei-Aghsaghali A, Maheri-Sis N. Nutritive value of some agro-industrial by-products for ruminants-A review. World J Zool. 2008;3(2):40-6.

32. Dairy One: Feed composition library. http://dairyone.com/analytical-services/ feed-and-forage/feed-composition-library/interactive-feed-composition-library/. Accessed Mar 2016.

33. Westendorf ML. Food waste to animal feed. USA: lowa State University Press; 2000.

34. Maciorowski KG, Herrera P, Jones FT, Pillai SD, Ricke SC. Effects on poultry and livestock of feed contamination with bacteria and fungi. Anim Feed Sci Tech. 2007:133(1-2):109-36.

35. Hu X, Hao W, Wang H, Ning T, Zheng M, Xu C. Fermentation characteristics and lactic acid bacteria succession of total mixed ration silages formulated with peach pomace. Asian Austral J Anim. 2015;28(4):502-10.

36. Tilley JMA, Terry RA. A two-stage technique for the in vitro digestion of forage crops. Grass Forage Sci. 1963;18(2):104-11.

37. Getachew G, Blümmel M, Makkar HPS, Becker K. In vitro gas measuring techniques for assessment of nutritional quality of feeds: A review. Anim Feed Sci Tech. 1998;72(3-4):261-81.

38. Makkar HPS. Recent advances in the in vitro gas method for evaluation of nutritional quality of feed resources, Assessing Quality and Safety of Animal Feeds. Rome: FAO Animal Production and Health Series; 2004. p. 160.

39. Nocek JE. Bovine acidosis: Implications on laminitis. J Dairy Sci. 1997;80(5): 1005-28.

40. Russell JB, O'connor JD, Fox DG, Van Soest PJ, Sniffen CJ. A net carbohydrate and protein system for evaluating cattle diets: I. Ruminal fermentation. J Anim Sci. 1992;70(11):3551-61.

\section{Submit your next manuscript to BioMed Central and we will help you at every step:}

- We accept pre-submission inquiries

- Our selector tool helps you to find the most relevant journal

- We provide round the clock customer support

- Convenient online submission

- Thorough peer review

- Inclusion in PubMed and all major indexing services

- Maximum visibility for your research

Submit your manuscript at www.biomedcentral.com/submit

) Biomed Central 